We acknowledge, with thanks, financial support from the Natural Sciences and Engineering Council of Canada.

\section{References}

Ball, R. G., Brown, R. S. \& Cocho, J. L. (1984). Inorg. Chem. 23, 2315-2318.

Baukova, T. V., Slovokhotov, Y. L. \& Struchkov, Yu. T. (1981). J. Organomet. Chem. 220, 125-137.

Bonati, F., Burini, A. \& Pietroni, B. R. (1989). J. Organomet. Chem. 375, 147-160.

Bonati, F., Burini, A. \& Pietroni, B. R. (1991). J. Organomet. Chem. 408, 271-208.

Canty, A. J., Michin, N. J., Healy, P. C. \& White, A. H. (1982). J. Chem. Soc. Dalton Trans. pp. 1795-1802.

Eggleston, D. S., Chodosh, D. F., WebB, R. L. \& Davis, L. L. (1986). Acta Cryst. C42, 36-38.

French, S. \& Wilson, K. (1978). Acta Cryst. A34, 517-525.
Gabe, E. J., Le Page, Y., Charland, J.-P., Lee, F. L. \& White, P. S. (1989). J. Appl. Cryst. 22, 384-387.

Howard-Lock, H. E., Lock, C. J. L., Penny, S. \& Turner, M. A. (1989). Can. J. Chem. 67, 1051-1055.

Lock, C. J. L. \& Turner, M. A. (1987). Acta Cryst. C43, 2096-2099.

Pauling, L. (1960). The Nature of the Chemical Bond, 3rd edition, pp. 221-230. Ithaca: Cornell Univ. Press.

Raubenheimer, H. G., Scott, F., Roos, M. \& Otte, R. (1990). $J$. Chem. Soc. Chem. Commun. pp. 1722-1723.

Schubert, U., Ackermann, K. \& Aumann, R. (1982). Cryst. Struct. Commun. 11, 591-594.

SHELDRICK, G. M. (1990). SHELXTL-Plus. Release 4.21/V. Siemens Analytical Instruments, Inc., Madison, Wisconsin, USA.

Stein, J., Fackler, J. P., Paparizos, C. \& Chen, H.-W. (1981). J. Am. Chem. Soc. 103, 2192-2198.

Usón, R., Laguna, A., Vicente, J., Garcia, J., Jones, P. G. \& Sheldrick, G. M. (1981). J. Chem. Soc. Dalton Trans. pp. 655-657.

Acta Cryst. (1992). C48, 1603-1606

\title{
Structure of Trimethylplatinum(IV) with a Tripod Ligand
}

\author{
By Richard E. Marsh, William P. Schaefer, David K. Lyon, Jay A. Labinger and John E. Bercaw \\ Division of Chemistry and Chemical Engineering* and The Beckman Institute, Mail Code 139-74, \\ California Institute of Technology, Pasadena, California 91125, USA
}

(Received 29 October 1991; accepted 4 February 1992)

\begin{abstract}
Cyclopentadienyl]-tris- $\mu$-(dimethylphosphito- $1 \kappa P: 2 \kappa O)\left(\right.$ trimethyl- $2 \kappa^{3} C$ ) cobaltplatinum, $\left[\mathrm{CoPt}\left(\mathrm{C}_{2} \mathrm{H}_{6} \mathrm{O}_{3} \mathrm{P}\right)_{3}\left(\mathrm{C}_{5} \mathrm{H}_{5}\right)\left(\mathrm{CH}_{3}\right)_{3}\right], M_{r}=691.35$, triclinic, $P \overline{1}, \quad a=9.106(3), \quad b=14.803(3), \quad c=$ 15.147 (3) $\AA, \alpha=112.95(2), \quad \beta=103.68(2), \quad \gamma=$ $95.10(2)^{\circ}, \quad V=1788.9(9) \AA^{3}, \quad Z=3, \quad D_{x}=$

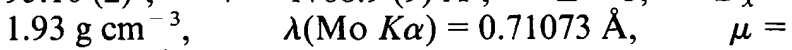
$68.69 \mathrm{~cm}^{-1}, F(000)=1014$, room temperature, $R=$ 0.038 for 4620 reflections with $F_{o}^{2}>3 \sigma\left(F_{o}^{2}\right)$. The trimethylplatinum(IV) completes octahedral coordination by bonding to three $\mathrm{O}$ atoms of the tripodshaped methoxy Kläui ligand. There are two independent molecules in the cell, one disordered about a center of symmetry. The ordered molecule has normal bond distances and angles; $\mathrm{Pt}-\mathrm{C}=$ 2.001 (11) and $\mathrm{Pt}-\mathrm{O}=2.173$ (5) $\AA$. Many distances in the disordered molecule are uncertain, particularly in the areas of the $\mathrm{Cp} \mathrm{C}$ atoms and the $\mathrm{CH}_{3}$ groups, which overlap in the two orientations.
\end{abstract}

Introduction. Interest in the activation and functionalization of saturated hydrocarbons by aqueous platinum chloride solutions (Shilov, 1984, 1989;

* Contribution No. 8533 .
Labinger, Herring \& Bercaw, 1990a,b) has led to our synthesizing model $\mathrm{Pt}$ complexes containing 'hard' ligands (Herring, Henling, Labinger \& Bercaw, 1991). Model complexes analogous to the putative $\mathrm{Pt}(R) \mathrm{Cl}_{4}\left(\mathrm{H}_{2} \mathrm{O}\right)^{-}$species that have been proposed as intermediates in the activation/functionalization of alkanes by Pt (Shul'pin, Shilov, Kitaigorodskii \& Zeile Krevor, 1980; Shibaera, Rozenberg, Lobkovskaya, Shilov \& Shul'pin, 1981; Shul'pin, Nizova \& Nikitaev, 1984; Khrushch, Laurushki, Misharin, Moravsky \& Shilov, 1983) are thus attractive targets, but few examples of structurally well characterized complexes are available. The tripod ligand $\left(\eta^{5}-\mathrm{C}_{5} \mathrm{H}_{5}\right) \mathrm{Co}\left[\mathrm{P}(\mathrm{O})(\mathrm{O} R)_{2}\right]_{3}^{-}$(henceforth abbreviated to $L_{\mathrm{O} R}$ ) behaves as a hard ligand, with field strengths approximately equal to that of three $\mathrm{F}^{-}$ligands (Kläui, 1990). Recently the synthesis of $\mathrm{Pt}\left(\mathrm{CH}_{3}\right)_{3} L_{\mathrm{O} R}$, where $R=\mathrm{Me}$ and $\mathrm{Et}$, as well as the crystal and molecular structure of the latter, have been reported (Nettle, Valderrama, Contreras, Scotti, Peters, von Schnering \& Werner, 1988). In the course of preparing these complexes for study of their chemical behavior, we obtained crystals of $\mathrm{Pt}\left(\mathrm{CH}_{3}\right)_{3} L_{\mathrm{OMe}}$, and decided to determine its structure for purposes of comparison. Formation of methanol

(C) 1992 International Union of Crystallography 
Table 1. Final refined positional parameters $\left(\times 10^{4}\right)$ and equivalent isotropic displacement parameters $\left(\AA^{2} \times 10^{4}\right)$ or isotropic displacement parameters $\left(\AA^{2}\right)$

$$
\text { for } \mathrm{Pt}\left(\mathrm{CH}_{3}\right)_{3} L_{\mathrm{OMe}}
$$

Atoms $010-018$ were refined with isotropic displacement parameters, $B$. Other atoms were refined with anisotropic displacement parameters; $U_{\text {eq }}=(4 / 3) \sum_{i} \sum_{j} U_{i j} a_{i}^{*} a_{j}^{*} \mathbf{a}_{i} . \mathbf{a}_{j}$.

\begin{tabular}{|c|c|c|c|c|}
\hline & $x$ & $y$ & $z$ & $B / U_{\text {сq }}$ \\
\hline Pt1 & $2511(.4)$ & $83(.2)$ & $2764(.3)$ & 480 (1) \\
\hline $\mathrm{Col}$ & $1646(1)$ & 2860 (1) & 3835 (1) & $461(2)$ \\
\hline Pl & $1247(3)$ & $1786(2)$ & 4439 (2) & $562(5)$ \\
\hline P2 & 3894 (3) & $2538(2)$ & $3770(2)$ & $637(6)$ \\
\hline P3 & $563(3)$ & $1736(2)$ & $2313(2)$ & $637(6)$ \\
\hline 01 & $1582(7)$ & $757(4)$ & 4009 (4) & 660 (15) \\
\hline $\mathrm{O} 2$ & 4151 (6) & $1493(4)$ & 3355 (5) & 768 (19) \\
\hline O3 & $893(7)$ & 700 (4) & 1966 (4) & 757 (19) \\
\hline $\mathrm{Cl}$ & 3991 (12) & $-443(7)$ & $3551(8)$ & $958(34)$ \\
\hline $\mathrm{C} 2$ & 988 (11) & $-1194(6)$ & $2237(8)$ & $853(33)$ \\
\hline C3 & $3368(12)$ & $-498(7)$ & $1599(8)$ & $913(31)$ \\
\hline 04 & $-508(8)$ & $1675(6)$ & 4439 (7) & $1252(26)$ \\
\hline OS & $2122(10)$ & $2288(5)$ & $5607(5)$ & $1122(29)$ \\
\hline 06 & $5049(7)$ & 3125 (5) & 4892 (6) & $1172(29)$ \\
\hline 07 & 4580 (11) & $3103(6)$ & $3232(8)$ & $1516(31)$ \\
\hline 08 & 918 (11) & $2203(5)$ & $1579(5)$ & $1254(31)$ \\
\hline 09 & $-1258(8)$ & $1631(5)$ & $2068(6)$ & $1168(29)$ \\
\hline Cpl & $7(14)$ & $3730(8)$ & 3829 (18) & 1157 (53) \\
\hline $\mathrm{Cp} 2$ & $1163(32)$ & 4061 (11) & 3524 (10) & $1188(51)$ \\
\hline Cp3 & 2464 (17) & $4364(8)$ & 4272 (19) & 1140 (52) \\
\hline $\mathrm{Cp} 4$ & $2172(24)$ & $4224(9)$ & 5059 (10) & $1102(52)$ \\
\hline Cp5 & $615(27)$ & $3823(10)$ & $4782(17)$ & $1122(46)$ \\
\hline $\mathrm{CA}$ & $-1368(17)$ & 858 (12) & 4427 (16) & $1977(70)$ \\
\hline $\mathrm{C} 5$ & 2962 (16) & $1859(9)$ & $6117(9)$ & $1295(48)$ \\
\hline C6 & 6446 (14) & $2898(10)$ & $5192(9)$ & $1239(45)$ \\
\hline C7 & $5176(21)$ & 2723 (13) & 2487 (14) & $1764(61)$ \\
\hline C8 & 841 (19) & $1643(10)$ & $591(9)$ & $1464(55)$ \\
\hline $\mathrm{CP}$ & $-2308(16)$ & 774 (11) & $1611(14)$ & $1742(69)$ \\
\hline $\mathrm{Pt} 2$ & $6392(1)$ & 4794 (1) & $-1149(1)$ & $432(2)$ \\
\hline $\mathrm{Co} 2$ & $4044(4)$ & $5141(3)$ & $853(3)$ & 496 (7) \\
\hline P4 & $4576(5)$ & $6252(3)$ & $315(3)$ & $500(10)$ \\
\hline P5 & 3303 (5) & 3954 (3) & $-666(4)$ & $628(12)$ \\
\hline P6 & $6382(5)$ & 4890 (4) & $1072(3)$ & 586 (11) \\
\hline 010 & 5174 (12) & $6014(7)$ & $-570(8)$ & $4.4(2)$ \\
\hline O11 & 7285 (12) & $4954(8)$ & $383(8)$ & $4.5(2)$ \\
\hline $\mathrm{O} 12$ & 4351 (12) & $3774(8)$ & $-1325(8)$ & $4.8(2)$ \\
\hline 013 & $5742(15)$ & $7213(10)$ & $1257(10)$ & $6.6(3)$ \\
\hline O14 & $2668(16)$ & 2880 (11) & -738 (11) & $7.8(3)$ \\
\hline 015 & $1678(16)$ & 4155 (11) & $-1246(11)$ & $7.7(3)$ \\
\hline 016 & 7445 (18) & 5615 (11) & 2199 (11) & 8.1 (4) \\
\hline 017 & $6316(17)$ & 3796 (11) & 1048 (11) & $8.1(4)$ \\
\hline 018 & 3124 (16) & $6774(10)$ & 94 (11) & $7.6(3)$ \\
\hline $\mathrm{Cl} 3$ & $6636(12)$ & $7956(7)$ & $1095(9)$ & 995 (34) \\
\hline $\mathrm{Cl} 4$ & 8953 (13) & $6202(9)$ & $2375(8)$ & $1157(43)$ \\
\hline $\mathrm{C} 15$ & 7574 (12) & 3243 (9) & $834(9)$ & 1049 (34) \\
\hline
\end{tabular}

during aqueous decomposition of $\mathrm{Pt}\left(\mathrm{CH}_{3}\right)_{3} L_{\mathrm{OR}}$ will be reported elsewhere.

Experimental. A truncated bipyramid crystal, $0.34 \times$ $0.30 \times 0.30 \mathrm{~mm}$, was used for data collection on a CAD-4 diffractometer with $\theta-2 \theta$ scans. 25 reflections with $36<2 \theta<38^{\circ}$ were used to determine cell dimensions. Data were not corrected for absorption effects $(\varphi$ scans showed relative transmissions of 0.97 to 1.03 , and the uncorrected data merged with a goodness of fit of 1.04). Data were collected to $(\sin \theta / \lambda)_{\max }=0.60 \AA^{-1} ; h$ from -10 to $10, k$ from -17 to $17, l$ from -18 to 18 . Three standard reflections ( $\overline{1} 24, \overline{3} 31$ and $0 \overline{1} \overline{4})$ showed a slight isotropic decay, for which a correction was made. 12652 reflections were measured, of which 6284 were independent $\left(R_{\mathrm{int}}=0.030\right.$ for 5449 reflections with exactly two observations). All reflections were used
Table 2. Selected distances $(\AA)$ and angles $\left({ }^{\circ}\right)$ for $\mathrm{Pt}\left(\mathrm{CH}_{3}\right)_{3} L_{\mathrm{OMe}}$

$\begin{array}{llll}\text { Pt1-O1 } & 2.168(6) & \text { P2-O2 } & 1.489(7) \\ \text { Pt1-O2 } & 2.178(6) & \text { P2-O6 } & 1.609(8) \\ \text { Pt1-O3 } & 2.174(6) & \text { P2-O7 } & 1.560(11) \\ \text { Pt1-C1 } & 1.998(11) & \text { P3-O3 } & 1.498(7) \\ \text { Pt1-C2 } & 1.991(10) & \text { P3-O8 } & 1.596(9) \\ \text { Pt1-C3 } & 2.013(11) & \text { P3-O9 } & 1.591(8) \\ \text { Co1-P1 } & 2.166(3) & \text { O4-C4 } & 1.37(2) \\ \text { Col-P2 } & 2.159(3) & \text { O5-C5 } & 1.331(16) \\ \text { Co1-P3 } & 2.168(3) & \text { O6-C6 } & 1.365(15) \\ \text { Co1-Cp1 } & 2.057(17) & \text { O7-C7 } & 1.32(2) \\ \text { Co1-Cp2 } & 2.07(2) & \text { O8-C8 } & 1.380(18) \\ \text { Col-Cp3 } & 2.066(19) & \text { O9-C9 } & 1.337(19) \\ \text { Co1-Cp4 } & 2.057(17) & \text { Cp1-Cp2 } & 1.37(3) \\ \text { Col-Cp5 } & 2.06(2) & \text { Cp1-Cp5 } & 1.37(3) \\ \text { P1-O1 } & 1.497(6) & \text { Cp2-Cp3 } & 1.33(3) \\ \text { P1-O4 } & 1.592(9) & \text { Cp3-Cp4 } & 1.37(3) \\ \text { P1-O5 } & 1.587(8) & \text { Cp4-Cp5 } & 1.38(3)\end{array}$

$\mathrm{O} 2-\mathrm{Ptl}-\mathrm{O} 1 \quad 88.1(2) \quad \mathrm{O}-\mathrm{P} 2-\mathrm{Col} \quad 106.9(3)$

$\mathrm{O} 3-\mathrm{P} t 1-\mathrm{O} 1 \quad 86.5(2) \quad \mathrm{O} 7-\mathrm{P} 2-\mathrm{Col} \quad 109.5(4)$

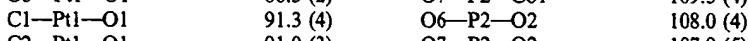

$\mathrm{C} 2-\mathrm{Ptl}-\mathrm{O} 1 \quad 91.0(3) \quad \mathrm{O} 7-\mathrm{P} 2-\mathrm{O} 2 \quad 107.9(5)$

$\begin{array}{llll}\mathrm{C} 3-\mathrm{Pt1}-\mathrm{O} 1 & 177.9(4) & \mathrm{O} 7-\mathrm{P} 2-\mathrm{O} 6 & 100.4(5)\end{array}$

$\mathrm{O} 3-\mathrm{Pt1}-\mathrm{O} 2 \quad 87.8(2) \quad \mathrm{O} 3-\mathrm{P} 3-\mathrm{Col} \quad 121.6(3)$

C2-Pt1-O2 $91.3(4)$

$\begin{array}{lrll}\mathrm{C} 2-\mathrm{Pt1}-\mathrm{O} 2 & 179.0(3) & \mathrm{O}-\mathrm{P} 3-\mathrm{Col} & 108.9(3) \\ \mathrm{C} 3-\mathrm{Pt1}-\mathrm{O} 2 & 90.6(4) & \mathrm{O}-\mathrm{P} 3-\mathrm{O} 3 & 108.5(4)\end{array}$

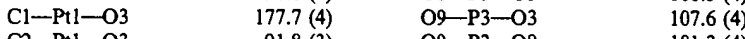

$\mathrm{C} 2-\mathrm{Pt1}-\mathrm{O} 3 \quad 91.8(3) \quad \mathrm{O}-\mathrm{P3}-\mathrm{O} 8 \quad 101.3$ (4)

$\mathrm{C} 3-\mathrm{Ptl}-\mathrm{O} 3 \quad 91.9(4) \quad \mathrm{Pl}-\mathrm{Ol}-\mathrm{Ptl} \quad 128.9$ (4)

$\mathrm{C} 2-\mathrm{Pt1}-\mathrm{Cl} \quad 89.1(4) \quad \mathrm{P} 2-\mathrm{O} 2-\mathrm{Ptl} \quad 129.4(4)$

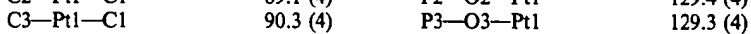

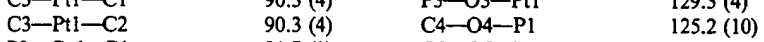

$\begin{array}{llll}\mathrm{P} 2-\mathrm{Co1}-\mathrm{Pl} & 91.7(1) & \mathrm{C} 5-\mathrm{O}-\mathrm{P} 1 & 126.1(8)\end{array}$

$\begin{array}{llll}\mathrm{P} 3-\mathrm{Col}-\mathrm{Pl} & 91.4(1) & \mathrm{C} 6-\mathrm{O} 6-\mathrm{P} 2 & 123.0(8)\end{array}$

P3- $\mathrm{Col}-\mathrm{P2} \quad 91.7$ (1) $\quad$ C7-O7-P2

$\mathrm{Ol}-\mathrm{Pl}-\mathrm{Col} \quad 122.2(3) \quad \mathrm{C}-\mathrm{O} 8-\mathrm{P} 3 \quad 124.1(9)$

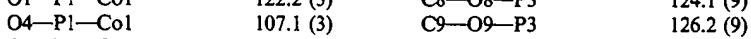

$\mathrm{OS}-\mathrm{P} 1-\mathrm{Col} \quad \mathrm{108.6(3)} \quad \mathrm{Cp5}-\mathrm{Cp} 1-\mathrm{Cp} 2 \quad 108.8$ (17)

$\mathrm{O} 4-\mathrm{Pl}-\mathrm{O} 1 \mathrm{Cp}-\mathrm{Cp} 2-\mathrm{Cpl} \quad 108.0(18)$

$\mathrm{OS}-\mathrm{Pl}-\mathrm{O} 1 \quad 107.6(4) \quad \mathrm{Cp} 4-\mathrm{Cp} 3-\mathrm{Cp} 2 \quad 109.2(17)$

$\mathrm{O} 2-\mathrm{P} 2-\mathrm{Col} \quad 122.0(3) \quad \mathrm{Cp} 4-\mathrm{Cp} 5-\mathrm{Cpl} \quad 106.3$ (18)

in solution and refinement of the structure. Pt and Co atom locations were deduced from a Patterson map; the locations of the remaining heavy atoms were found from successive structure factor-Fourier calculations. $F^{2}$ values were used in the refinement. $\mathrm{H}$ atoms on the ordered molecule were placed by calculation ( $\mathrm{C}-\mathrm{H} 0.95 \AA$ ) assuming staggered geometry; $\mathrm{H}$-atom parameters were not refined, but were included as constant contributions to the structure factors; $\mathrm{H}$ atoms were not introduced on the disordered molecule. Coordinates and anisotropic displacement parameters of all heavy atoms of the ordered molecule, a scale factor and a secondaryextinction parameter (Larson, 1967) were refined. In the disordered molecule the Co and Pt atoms, which are separated by $0.65 \AA$, were refined satisfactorily as half-weight anisotropic atoms. The three $\mathbf{P}$ atoms were also refined as half-weight anisotropic atoms, and the nine $\mathrm{O}$ atoms as half-weight isotropic atoms. On the other hand, the six $\mathrm{C}$ atoms of the methoxy groups appeared to be closely overlapped in the two orientations, and were refined as three full-weight anisotropic atoms. Overlap of the five atoms of the $\mathrm{Cp}$ ring with the three Pt-coordinated methyl groups was complicated; these atoms were placed in idea- 
lized half-populated sites with isotropic $B$ values and not refined. The final difference map clearly showed that the modeling in this area was incomplete, presumably because of the neglect of the large anisotropies in the $U_{i j}$ values expected for such atoms. For all 5754 reflections with $F_{o}^{2}>0$, final $R$ (on $F$ ) = $0.051, w R$ (on $\left.F^{2}\right)=0.008 ; S=1.81$. Weights were taken as $1 / \sigma^{2}\left(F_{o}^{2}\right)$; variances $\left[\sigma^{2}\left(F_{o}^{2}\right)\right]$ were derived from counting statistics plus an additional term,

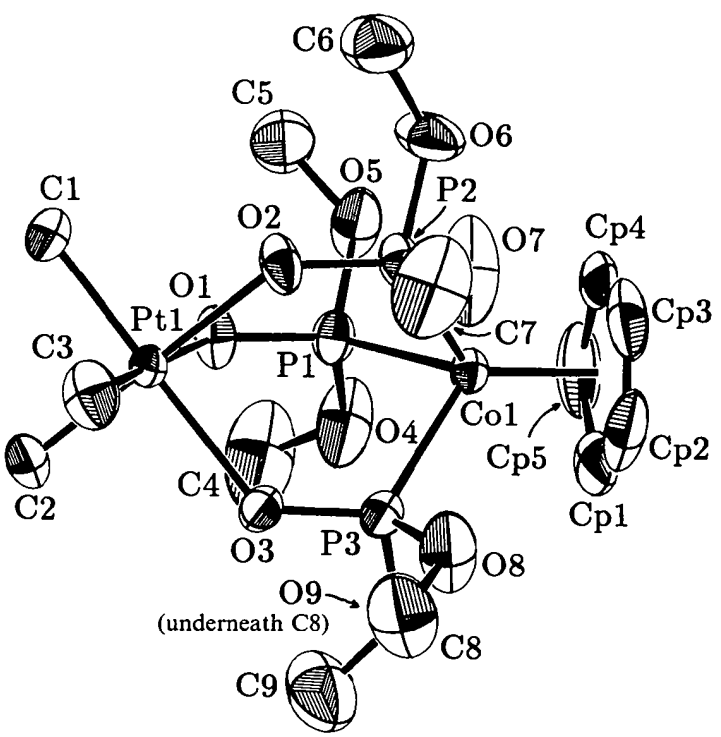

Fig. 1. An ORTEPII (Johnson, 1976) drawing of the ordered cation with $50 \%$ probability ellipsoids showing the numbering system. $\mathrm{H}$ atoms are not shown.

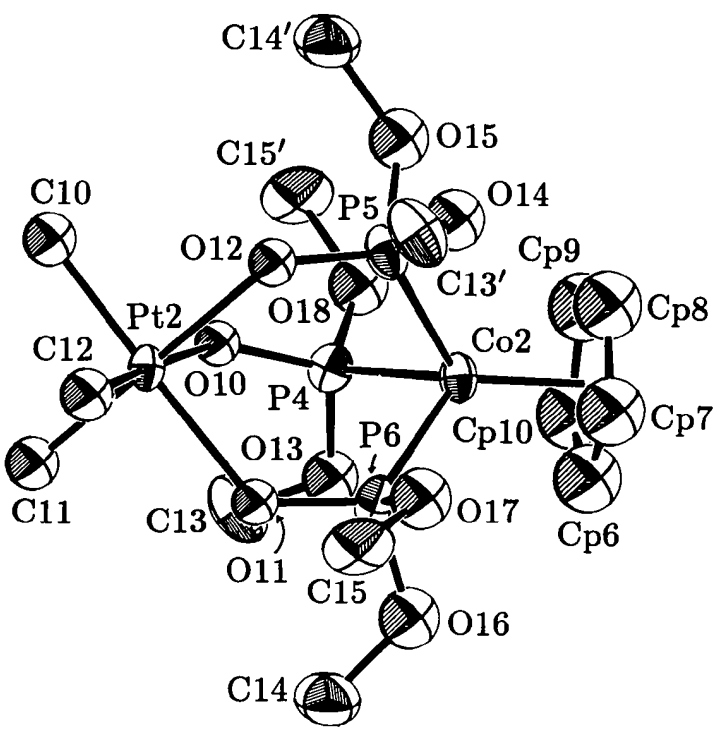

Fig. 2. An ORTEPII (Johnson, 1976) drawing of the disordered cation with $50 \%$ probability ellipsoids showing the numbering system. Primed atoms are related to unprimed atoms by a center of symmetry.
$(0.014 I)^{2}$, variances of the merged data by propagation of e.s.d. plus another additional term, $(0.014 \bar{I})^{2}$. The ratio of maximum shift to standard deviation in the final cycle was 0.03 ; maximum and minimum peaks in the final difference map were 1.33 (near the $\mathrm{Cp}$ ring on the disordered molecule - the five largest peaks are in this region) and $-1.01 \mathrm{e} \AA^{-3}$ $(0.7 \AA$ from $\mathrm{P} 3)$; the secondary-extinction parameter refined to $0.94(3) \times 10^{-6}$. Atomic scattering factors were taken from Cromer \& Waber (1974) and dispersion corrections from Cromer (1974). Programs used were those of the $C R Y M$ crystallographic computing system (Duchamp, 1964) and ORTEPII (Johnson, 1976). Final refined parameters are listed in Table 1 with selected distances and angles in Table 2. The two independent molecules are shown in Figs. 1 and 2 ; Fig. 3 shows the packing.*

Discussion. The molecular structure of $\mathrm{Pt}\left(\mathrm{CH}_{3}\right)_{3} L_{\mathrm{OMe}}$ is quite similar to that previously reported for the ethyl analog, which in turn displays structural parameters closely resembling those of other complexes containing the $L_{\mathrm{O} R}$ tripod ligand as well as those with the $\mathrm{PtMe}_{3}$ moiety (Nettle et al., 1988).

* Lists of assigned $\mathrm{H}$-atom parameters, anisotropic displacement parameters, complete distances and angles, and observed and calculated structure factors have been deposited with the British Library Document Supply Centre as Supplementary Publication No. SUP 55138 (34 pp.). Copies may be obtained through The Technical Editor, International Union of Crystallography, 5 Abbey Square, Chester CH1 2HU, England. [CIF reference: HH0605]

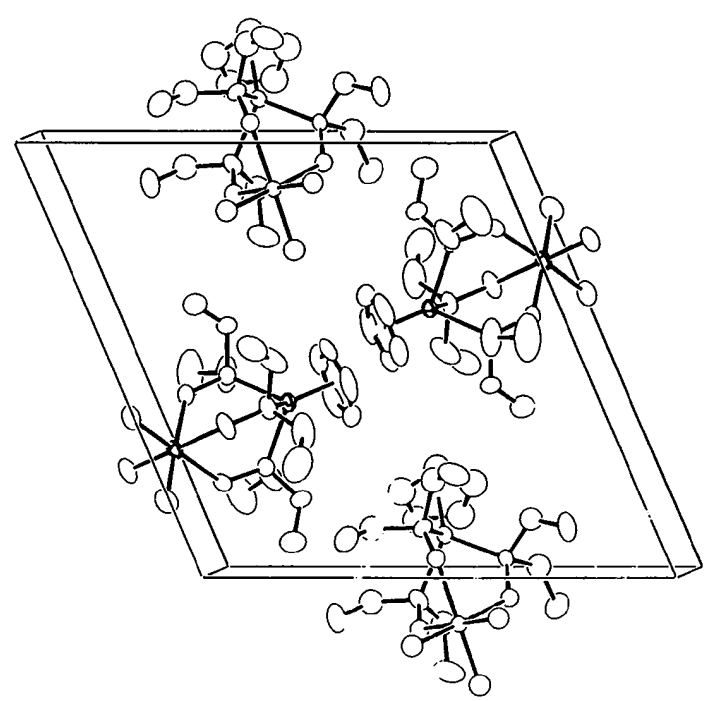

Fig. 3. An ORTEPII (Johnson, 1976) packing drawing projected approximately down $a$ showing the contents of a unit cell, with the unit cell outlined. The $c$ axis is horizontal. Atoms are shown as $50 \%$ probability ellipsoids, with $\mathrm{Co}$ and $\mathrm{Pt}$ atoms of the ordered cation shaded; $\mathrm{H}$ atoms are not shown. Only one orientation of the disordered cation is shown. 
Comparing bond distances and angles between the two $\mathrm{Pt}\left(\mathrm{CH}_{3}\right)_{3} L_{\mathrm{OR}}$ structures, nearly all agree to within experimental uncertainty. The only apparently significant differences are found in the $\mathrm{P}=\mathrm{O}-\mathrm{Pt}$ linkages: the average values for $\mathrm{Pt}-\mathrm{O}, \mathrm{O}-\mathrm{P}$ and $\mathrm{Pt}-\mathrm{O}-\mathrm{P}$ are $2.196(1), 1.507(8) \AA$ and $125.1(9)^{\circ}$ for $\mathrm{Pt}\left(\mathrm{CH}_{3}\right)_{3} L_{\mathrm{OEt}}$, and $2.173(5), 1.492(6) \AA$ and $129.2(3)^{\circ}$ for the ordered molecule of $\operatorname{Pt}\left(\mathrm{CH}_{3}\right)_{3} \mathrm{~L}_{\mathrm{OMe}}$, respectively. (Values for the disordered molecule are intermediate, but the uncertainties in these parameters are considerably larger and their significance is dubious.) Increased steric crowding around the set of $\mathrm{P}=\mathrm{O}$ ligands could result in a greater separation between the tripod ligand and the Pt center and the observed increase in bond lengths for $\mathrm{Pt}\left(\mathrm{CH}_{3}\right)_{3} L_{\mathrm{OEt}}$, but this interpretation predicts an increase in $\mathrm{Pt}-\mathrm{O}-\mathrm{P}$ angles, whereas a decrease is found.

The crystal structure of $\mathrm{Pt}\left(\mathrm{CH}_{3}\right)_{3} L_{\mathrm{OMe}}$ exhibits an interesting feature: of the two independent molecules in the unit cell, one is disordered about a center of symmetry (Fig. 2). It may be noteworthy that each of the six $\mathrm{C}$ atoms of the methoxy groups virtually overlaps its partner in the other orientation of the disordered molecule; perhaps the breaking of this pseudo-symmetry element by additional substitution is responsible for the fact no such disorder was found for the ethyl analog.

This work was supported by the Office of Naval Research, Grant No. N00014-89-J-3198. We thank Dr Gerrit Luinstra for helpful discussion.

\section{References}

Cromer, D. T. (1974). International Tables for X-ray Crystallography, Vol. IV, pp. 149-151. Birmingham: Kynoch Press. (Present distributor Kluwer Academic Publishers, Dordrecht.)

Cromer, D. T. \& WABER, J. T. (1974). International Tables for $X$-ray Crystallography, Vol. IV, pp. 99-101. Birmingham: Kynoch Press. (Present distributor Kluwer Academic Publishers, Dordrecht.)

DuCHAMP, D. J. (1964). CRYM crystallographic computing system. Am. Crystallogr. Assoc. Meet., Bozeman, Montana. Paper B14, p. 29.

HerRING, A. M., Henling, L. M., Labinger, J. A. \& BerCaw, J. E. (1991). Inorg. Chem. 30, 851-853.

JoHNSON, C. K. (1976). ORTEPII. Report ORNL-3794, third revision. Oak Ridge National Laboratory, Tennessee, USA.

KhrushCh, L. A., Laurushi, V. V., Misharin, Y. S., Moravsky, A. P. \& Shilov, A. E. (1983). Nouv. J. Chem. 7, 729-733.

$\mathrm{K}_{\perp A ̈ U}, \mathrm{~W}$. (1990). Angew. Chem. Int. Ed. Engl. 29, 627-637.

Labinger, J. A., Herring, A. M. \& BercaW, J. E. (1990a). J. Am. Chem. Soc. 112, 5628-5629.

Labinger, J. A., Herring, A. M. \& Bercaw, J. E. (1990b). Am. Chem. Soc. Symp. Ser. In the press.

Larson, A. C. (1967). Acta Cryst. 23, 664-665.

Nettle, A., Valderrama, M., Contreras, R., Scotti, M., Peters, K., von Schnering, H. G. \& Werner, H. (1988). Polyhedron, 7, 2095-2101.

Shibaera, R. P., Rozenberg, L. P., LobKovskaya, R. M., ShIlov, A. E. \& Shul'pIN, G. B. (1981). J. Organomet. Chem. 220, 271-276.

Shilov, A. E. (1984). Activation of Saturated Hydrocarbons by Transition Metal Complexes. Dordrecht: Reidel.

SHuOv, A. E. (1989). Activation and Functionalization of Alkanes, edited by C. L. Hill, pp. 1-26. New York: John Wiley.

Shul'pin, G. B., Nizova, G. V. \& Nikitaev, A. T. (1984). J. Organomet. Chem. 276, 115-153.

Shul'pin, G. B., Shilov, A. E., Kitaigorodskil, A. N. \& Zeile Krevor, J. V. (1980). J. Organomet. Chem. 201, 319-325.

Acta Cryst. (1992). C48, 1606-1609

\title{
Structures of the Nickel(II) and Copper(II) Complexes of 3-Hydroxy-6-methylpyridine-2-thione
}

\author{
By Jean A. Boyko, William F. Furey JR* and Roger A. Lalancette $\dagger$ \\ Carl A. Olson Memorial Laboratories, Department of Chemistry, Rutgers University, Newark, NJ 07102, \\ USA
}

(Received 2 January 1991; accepted 10 March 1992)

\begin{abstract}
I) Bis(6-methylpyridine-2-thion-3-olato)nickel(II) bis(dimethylformamide), $\mathrm{Ni}\left(\mathrm{C}_{6} \mathrm{H}_{6} \mathrm{NOS}\right)_{2}$.$2 \mathrm{C}_{3} \mathrm{H}_{7} \mathrm{NO}, \quad M_{r}=485.28$, monoclinic, $P 2_{\mathrm{l}} / c, a=$ $8.518(2), \quad b=13.545(2), \quad c=9.340(1) \AA, \quad \beta=$

\footnotetext{
* Present address: Veterans Administration Hospital, University

† To whom correspondence should be addressed.
} of Pittsburgh, USA.
\end{abstract}

0108-2701/92/091606-04\$06.00 $94.19(2)^{\circ}, \quad V(241 \mathrm{~K})=1074.7(4) \AA^{3}, \quad Z=2$, $D_{m}(295 \mathrm{~K})=1.53(1), D_{x}\left[295 \mathrm{~K} ; \quad V=1086.4(3) \AA^{3}\right]$ $=1.48 \mathrm{~g} \mathrm{~cm}^{-3}, \quad \lambda(\mathrm{Cu} K \alpha)=1.5418 \AA, \quad \mu=$ $31.47 \mathrm{~cm}^{-1}, F(000)=508, T=241(1) \mathrm{K}, R=0.0500$ for 1240 observed reflections. The complex is planar with the $\mathrm{Ni}$ ion at the origin of the unit cell. A hydrogen bond exists between the $\mathrm{N}-\mathrm{H}$ of the ligand and the carbonyl $O$ atom of the

(C) 1992 International Union of Crystallography 